С. І. Єрмоленко

\title{
СТУДІЮВАННЯ У ВИШАХ КАТЕГОРІЙ «ПІДТЕКСТ» I «КОНТЕКСТ» (НА ПРИКЛАДІ АНТОЛОГІЇ «ДЕКАМЕРОН»)
}

Срмоленко C. I. Студіювання у вишах категорій «підтекст» i «контекст» (на прикладі антології «Декамерон»).

У статті описано сучасне студіювання у вишах категорій «підтекст» і «контекст», визначено основні напрями в методиці навчання лінгвістичного аналізу тексту студентів філологічного факультету. На прикладі антології «Декамерон» доведено, що 
в постмодерній літературі двотисячних 3'явилися певні тенденції щодо передачі категорій «контекст» і «підтекст» на різних мовних рівнях.

Ключові слова: підтекст, контекст, мовознавчий i літературознавчий аналіз художніх текстів, лінгводидактика, методи навчання.

Ермоленко С. И. Изучение в высших учебных заведениях категорий «подтекст» и «контекст» (на примере антологии «Декамерон»).

В статье описывается современное изучение в высших учебных заведениях категорий «подтекст» и «контекст», определены главные направления в методике обучения лингвистическому анализу текста студентов филологического факультета. На примере антологии «Декамерон», иллюстративно доказывается, что в постмодернистской литературе двухтысячных появились определённые тенденции по передаче категорий «контекст» и «подтекст» на разных языковых уровнях.

Ключевые слова: подтекст, контекст, языковедческий и литературоведческий анализы художественных текстов, лингводидактика, методы обучения.

Yermolenko S. I. Study of the categories "subtext" and "context" in the higher educational institutions (case study: the anthology "Decameron").

The article deals with the contemporary study of such categories as "subtext" and "context" in the higher educational institutions. There has been determined the main trends in the field of the teaching methodology of the linguistic analysis of the text by the students of the Philology Department. Taken the anthology "Decameron" as a case study the author asserts that the postmodern literature of the $2000^{\text {th }}$ is characterized by the emergence of certain trends regarding the expression of such categories as "context" and "subtext" on different linguistic levels.

Key words: subtext, context, linguistic and literary criticism analysis of literary texts, linguodidactics, teaching techniques.

У післямові Сергій Жадан стверджує: «Втім, надзвичайно тішуся, що вона [антологія] має вигляд саме такий, що в ній містяться тексти людей, які для мене особисто багато в чому і визначали літературні двотисячні, принаймні вони, люди й тексти, цілком укладаються в ці десять років життя та літератури, виступаючи щодо них свідками та підозрюваними водночас... Натомість тексти, тут уміщені, будуть цікаві читачам, які люблять літературу, незалежно від включеності в контекст» [2, с. 312-316].

Отже, нам потрібно визначити, що позначають поняття «контекст» $\mathrm{i}$ «підтекст». У малій філологічній енциклопедії зазначається: «Контекст 1. Уривок тексту, що має закінчену думку, дає змогу визначити сенс певного слова або фрази, які входять до його складу. 2. Мовне оточення певної лінгвальної одиниці, умови, особливості вживання певного елемента в мові» [3, с. 193]. Там же: «Підтекст - це виражений словами внутрішній сенс висловлювання, який розуміють за «опущеними», «викинутими» членами речення або за натяками» [3, с. 313].

Актуальність нашого дослідження полягає в тому, щоб на прикладі антології «Декамерон», яка репрезентує українських письменників початку XXI сторіччя (двотисячні), розкриємо основні тенденції розвитку лінгвістичного аналізу тексту на сучасному етапі, а саме: лексичний i 
граматичний рівні, стилістичні особливості в побудові різних конструкцій речень тощо - опишемо категорії «контекст» і «підтекст» на рівні дискурсивного аналізу коротких епічних текстів (оповідань, психологічних новел).

Багато сучасних вітчизняних і зарубіжних мовознавців і літераторів, філософів, лінгводидактів опрацьовують категорії «контекст» і «підтекст» у різних напрямках вивчення (лінгвістика, літературознавство, філософія, психологія, лінгводидактика), це такі, як Й. Гальперін, Г.-Г. Гадамер, Т. Донченко, В. Корнєв, А. Матчук, Е. Хемінгуей, В. Шприкевич та інші.

Meта нашого дослідження полягає в тому, щоб репрезентувати категорії «контекст» і «підтекст» 3 різних напрямків вивчення, а саме: лінгвістичного, літературознавчого, психологічного, філософського та лінгводидактичного. Основні завдання, які передбачено автором: 1) ознайомити з останніми дослідженнями; 2) опрацювати і систематизувати здобуті знання; 3) реалізувати їх у набутих уміннях і навичках; 4) зробити висновки; 5) передбачити перспективи подальшого студіювання.

Більшість творів української літератури постмодерного періоду функціонують саме завдяки підтексту - якби не було підтексту, не було б і цих творів. По суті, в усіх психологічних новелах, оповіданнях 85\% важливої для розуміння художнього тексту інформації письменник доносить до читача через підтекст, а не контекст.

Будь-який літературний твір - не лише мистецьке полотно, а й носій певної інформації. Згідно із запропонованою класифікацією російського критика, публіциста, поета Й. Гальперіна, у тексті обов'язково присутні такі види інформації: змістовно-фактична: дає повідомлення про факти, події, процеси, що відбуваються у світі; змістовно-концептуальна повідомляє читачеві індивідуально-авторське розуміння певних явищ чи подій; така інформація виділяється з тексту художнього твору і $є$ творчим переосмисленням самого автора; змістовно-підтекстова - несе приховану інформацію, узяту із змістовно-фактичної.

За словами німецького філософа Г.-Г. Гадамера, основною сферою зацікавлень якого був взаємозв'язок філософії та літератури, зокрема поезії, твір повинен сприйматися в певному контексті, який він називає «живим досвідом» [1, с. 216]. Контекст немов додає виразності інтерпретації підтексту.

Для того щоб реципієнт задіяв свої інтуїтивні можливості для виявлення і розуміння підтексту, автор будує художній текст так, щоб відповіді на поставлені запитання можна було знайти лише в підтекстових структурах.

Проаналізуємо психологічну новелу Софії Андрухович «death is sexу» (смерть - це секс). У заголовку дається глибокий підтекст того, про що буде мова далі, а саме про дівчину, приречену на смерть, і найманого вбивцю, який мав би іiі «порішити» зразу ж при зустрічі, але вирішив 
випалити «косячок» (наркотичну цигарку) і розповісти про свої проблеми, адже вона їх нікому не зможе розповісти після смерті..., відійшовши від звичного сценарію вбивства, чоловік втратив контроль над ситуацією, а наркотики i секс призвели до інфаркту і смерті вбивці, а жертва зникла десь у часі...

Як і всі постмодерні тексти, цей текст характеризується поєднанням художнього і розмовного мовлення; тому текст перенасичений діалогами (- Я можу з тобою поговорити. - Що? -Ти хотів поговорити. Я не проти. - Та ні, ие погана ідея. Не можна. Не треба. - ..-Ти справді можеш? Можу. - Але пообіияй, не будеш сподіватись на те, щзо... Бо иъього не буде. - Я знаю. - Точно? [2, с. 16-17]), простими реченнями, які ускладнені однорідними членами (Вона здригнулась $і$ застогнала [2, с. 10]), (Вона затихла, напружилась $i$ дивилась на нього спідлоба, не кліпаючи [2, с. 11]), відокремленими означеннями (Сірі бетонні сходи, неоковирні, широкі, вели догори, і чоловік повів ними дівчину, взявши ї̈ вузьку й легку долоню у свою велику, гарячу, порепану [2, с. 18]), обставинами (Закінчивши забивати, він гойднувся вперед на табуреті $i$ добряче штовхнув ї̈ в спину підошвами свої високих шнурованих черевиків [2, с. 5]), (Він вів ї̈, тримаючи за лікоть, довгим $і$ темним коридором, підсвічуючи молільником [2, с. 17]), вставними і вставленими конструкціями (На протертій тахті серед подушок з китицями міцно спав пес із роду тер 'срів (можсливо, жсердель), хропучи й повискуючи крізь сон, час від часу посмикуючи лапою [2, с. 25]), називними односкладними реченнями, неповними реченнями (Або, хочеш - можеш сама вибрати [2, с. 11]), непоширеними реченнями (Це було складно. Це було майже неможливо [2, с. 13]); (Двері прочинені. За дверима - чорно... завмерла. Прислухалась. Зовсім тихо [2, с. 14]) (синтаксичний рівень); жаргонна лексика (Ой, бля... [2, с. 6]), просторіччя (Чуєи, дримбо, давай покуримо... [2, с. 5]); (У тебе є щзось пожерти, морячок? [2, с. 9]) (лексичний рівень); порівняльні звороти (Волосся позлипалось від крові і моторошно блищзало, мов вимащене смолою, у тьмяному світлі єдиної на весь цуех вцілілої лампи [2, с. 6]), (Наче добрі знайомі, котрі зустрічались так уже сотні разів $i$ зовсім не дивувалися цим зустрічам. Як старе подружнжя, призвичаєне до щзоденних ритуалів... [2, с. 14]), (Полонянка на долю секунди підняла на нього погляд - i очі ї̈ були, як очі арктичної вовчиці [2, с. 22]), риторичні запитання i накопичення заперечень (часте використання заперечних часток) для передачі відносності того, що сталося ( А дівчину не знайдуть, ні, ї̈ не знайдуть ніколи. Якщзо дотепер не знайшли - чому раптом зараз мали би? [2, с. 32]), повтори для створення ефекту непереривності і незакінченості чогось у часі (Це тривало $i$ тривало [2, с. 9]), а також для передачі прохання (Відпусти мене, прохрипіла вона. - Ну, будь ласка, ну, я дуюе, я дуже-дуже прошу тебе, відпусти мене. Ну, будь ласка [2, с. 32]), незакінчені речення для 
створення ефекту незавершеності й продовження в часі, недомовленості (Нічого не знати про того, кого я...[2, с. 10]); (У мене дещз сталося ... В моєму житті... Дещзо таке, щзо вибило з колї... Розумієш... [2, с. 11]) (стилістичний рівень).

Як символічний образ або алегорію можна сприйняти в оповіданні татуювання на спині жертви, які вразили вбивцю: Чоловік зауважив раптом химерні татуювання на ї̈ плечах, двічі перекреслені бретельками майки: кілька комах - бабка, богомол, капустянка і два-три жуки, щзо наче виповзли з-під одягу, - ї̈ блідій холодній шкірі личила ияя графіка, тонкі бездоганні лінії, перетинки на крилах, вусики, чутливі лапки. Комахи ворушилися й шурхотіли. 3-під майки виборсалося кілька лінивих мотилів $і$ поповзли вгору лінією хребта до потилиці. «То он звідки вони беруться», подумав чоловік, переводячи погляд на торшер, майже повністю, до чорноти обліплений комахами [2, с. 10]. Зрозуміло, що усе це йому привиділося під дією наркотичних засобів, спожитих без міри (косяки), тому другу частину оповідання автор оформив у вигляді накопичення різних однорідних конструкцій, що передають інтер'єр верхніх поверхів зруйнованого заводу і кімнати, до якої ввійшли вбивця та жертва, а також у перерахуванні харчів, які чомусь зберігаються в цьому покинутому приміщенні, в описі пса... - все це допомагає нам сприймати цю частину тексту, як напівфантастичні галюцинації головного героя, що втратив зв'язок із реальним світом уже не тільки духовно, але й фізично.

Знахідкою Софії Андрухович є використання обтяжливих різними синтаксичними зв'язками синтаксичних конструкцій у зображенні вражень випадкових свідків фатальної ночі - юнги та проститутки: Десь там, знав чоловік, сплять моряки у своїх гойдливих ліжках, там хлюпочеться мляво риба і вряди-годи скрикує насторожена, збентежена чайка $i$, схиливиись над просмаленими канатами старого пірсу, худа проститутка обережно підтримує голову молоденького юнги, щзо, проплювавшись у піну прибою, зачудовано вдивлясться вниз, у шепіт хвиль, і бачить, як самиця жсиафи, злизуючи тверде, гірке та холодне грушеве листя своїм жорстким, мов натренований м'яз, темно-гранатовим язиком, аж до болю напружуючи шию та вивертаючи яблука прекрасних сумних очей, крізь витинанку гілок прагне роздивитися двох, щзо розпластались на старому ліжку, на вицвілих шовкових простирадлах, і простирадла иі на дотик, мов брили льоду такі ж пластичні й нестерпні, і не гріють, не гріють ц̧их двох коханців, цүю дівчину, довготелесу, закривавлену, виснажену, схожу на коникастибуния, на бабку зі смарагдовими крильиями, на водомірку, $і$ доброго чоловіка із зашкарублими руками, з брудом під нігтями, з кров'ю, щуо запеклася на його долонях, иього чоловіка, в змориках обличчя якого ховається і голод хижака, і втома та неспокій травоїдного [2, с. 31].

Софія Андрухович змушує читача заглиблюватися в контекст i розгортати його смисли в пошуках відповідей. Із літературознавчого 
погляду кінцівка твору є «пуантом - гостро драматичним завершенням сюжету твору» $[4$, с. 580$]$, що спонукає до заглибленого розгортання його смислів.

Для створення прихованих смислів твору кожен талановитий автор використовує «принцип айсберга» (за висловом Е. Хемінгуея) - такий спосіб зображення подій, за якого на видимій поверхні тексту міститься лише незначна частина інформації, необхідної для розуміння ідеї твору, а більша й важливіша іiі частина перебуває в підтексті. Іншими словами, «принцип айсберга» сам є концептуальним художнім прийомом створення підтексту і становить систему мовних та композиційних прийомів, що працюють на його реалізацію.

3 усіх відомих засобів творення підтексту діалог як форма тексту найкращим чином реалізує мету створити «айсбергові» приховані смисли, бо співрозмовники часто добре знають одне одного, а отже, можуть свідомо чи несвідомо вилучати з розмови певні зрозумілі для них, але аж ніяк не для читача! - смисли. Завдяки цьому композиційному прийому автор змушує читача до прискіпливого прочитання.

Ще одним дійовим способом зображення подій, який ефективно працює на створення підтексту твору і який можна назвати «підтекстом у підтексті», є алегорія. Наприклад, у новелі Анатолія Дністрового «Біла дівчинка» розповідається про незвичайну дівчинку, яка раптом з'явилася на околиці міста. Люди, до яких вона доторкалася, також ставали білими, їхнє життя змінювалося кардинально: вони отримували бездоганне здоров'я, новий погляд на речі. Це спричинило паніку в усіх звичайних «сірих» людей, які не хотіли змінюватися, відтак оголосили білих людей зараженими невідомою хворобою і помістили до карантинної зони. Коли дівчинка повернулася другий раз на околиці міста, то зрозуміла, що іiі прихід занадто ранній у часі, люди ще не готові до таких змін, тому вона зникла. Біла дівчинка - це людина, яка живе в гармонії з довкіллям. У нашому збоченому світі люди перестали вірити звичайним природним речам, стали недовіряти один одному, посіяли цинізм, який спустошує їхні душі, а це сприяє розвитку фізичних вад, нездоров'я, таким чином, втрачається гармонія. Підтекстовий смисл алегорії пояснює сучасні духовні та фізичні проблеми людей, які живуть у дисгармонії з довкіллям.

Для побудови прихованого плану використовуються й інші художні прийоми, які є характерними саме для підтексту, насамперед це повтори: лексичні, синтаксичні, емоційно-оцінні та ситуативні. Завдяки повторам автор вибудовує так звані «лейтмотиви-пунктири»: варіативне побіжне згадування протягом уривка або всього тексту подій, реплік, рис характеру, поведінки тощо для вираження певної думки, ідеї. Це також і еліптичні, тобто незакінчені, репліки.

Важливим художнім прийомом, що активно працює на створення підтексту, $є$ темпоритм, який твориться за допомогою лексико- 
синтаксичних повторів, використання ідентичних граматичних структур і багато в чому залежить від контекстуального їх наповнення (тобто змісту й ситуації, у якій цей зміст реалізується). Наприклад, в оповіданні Любка Дереша «Клуб молодих вдів» підтримується швидкий темпоритм (через прості неускладнені речення), тому що головний герой не пам'ятає свого минулого - воно для нього, як калейдоскоп, але воно постійно переслідує його через колишніх вдів, які не можуть змиритися з втратою коханого: На вулиці сильний туман. Але ми проведемо вас, маестро. 3 нами ви у повній безпеці. Ми впізнаємо вас де завгодно [2, с. 53].

Чи в кожному творі $є$ підтекст? Чи не вдаються сучасні критики й деякі літературознавці часом до маніпулювання читацькою свідомістю?

Для розуміння художнього твору псевдопідтекст - явище шкідливе. Його взірцем є фрустраційні, тобто такі натуралістично-порнографічні елементи в сучасній прозі. Виникає явище зумисного нав'язування читачеві думки про власну недолугість, якщо той має сумнів у геніальності твору. Так моделюється ситуація, влучно описана Г. Х. Андерсоном у казці «Нове плаття короля».

А. Матчук пропонує розрізняти такі види псевдопідтексту» [5, с. 97]: 1) підтекст-ілюзія - читач вірить у підтекст, хоча автор виражає свої думки прямо й надто відверто (Ірена Карпа в оповіданні «Цукерки, фрукти i ковбаси» - це просто спогади автора про своє дитинство і ранню юність); 2) підтекст-фікція - відсутність думки у творі прикривається складними для розуміння семантичними й синтаксичними конструкціями, які автор подає як щось значуще (Сашко Ушкалов в оповіданні «Панда» розповідає про перетворення людини в панду, за круговертю перипетій головного героя важко знайти якесь логічне пояснення такому перетворенню); 3) підтекстміраж - який запрограмований автором спеціально, задля ідеологічної дезорієнтації читача (Світлана Пиркало в оповіданні «Життя. Цілувати» вносить спеціально підтекст після заголовку (Текст містить лексику й описи ситуацій, які деяким читачам можуть здатися образливими [2, с. 145]), розповідає про пошук пари головною героїнею в туманному Альбіоні (Англії), про неочікуваного обранця Зорана. Нам важко після прочитання оповідання відповісти: чи правильно вважати Зорана циніком і пройдисітом, чи, навпаки, він $є$ позитивним героєм, здатним на справжні глибокі почуття. Крилатий вислів Зорана: «Життя закоротке, щзоб цүілувати крокодилів...» [2, с. 145] - парадоксальний простотою світосприймання героя).

Усе, що зображується у художньому творі (герої, події, хронотип), бачиться чиїмись очима i втілюється в чиємусь слові. Слово першооснова літературного твору. Тому найпродуктивніший спосіб дослідження постмодерної літератури - це шлях від окремого слова до системи образів, а згодом - до змісту як втіленої художньої цілісності. Слово сказане (контекст) i несказане (підтекст) насамперед втілює художню концепцію автора. 
Нинішній студент не почувається безпорадним навіть у разі самостійного лінгвістичного аналізу постмодерного твору, оскільки $є$ високоінтелектуальною людиною, яка черпає інформацію 3 багатьох джерел, уміє іiі порівнювати. Належне скерування викладача тільки активізує студентів і допомагає їм глибоко розуміти відмінності світогляду письменників, стилю кожного окремо взятого постмодерного твору.

\section{Література}

1. Гадамер Г.-Г. Про вклад поезії у пошук істини // Слово. Знак. Дискурс: Антологія світової літературно-критичної думки $\mathrm{XX}$ ст. / За ред. М. Зубрицької. - Л. : Літопис, 1996. - С. 216-222.

2. Декамерон. 10 українських прозаїків останніх десяти років [Текст] : збірка / Укладання та післямова С. Жадана. - Харків : Книжний Клуб «Клуб Сімейного Дозвілля», 2010. - 320 с.

3. Мала філологічна енциклопедія / Уклали : О. І. Скопненко, Т. В. Цимбалюк. К. : Довіра, 2007. - 478 с.

4. Літературознавчий словник-довідник / Р. Т. Гром'як, Ю. І. Ковалів та ін. - К. : ВЦ «Академія», 1997. - $752 \mathrm{c.}$

5. Матчук А. Подтекст литературного произведения : дис. ... канд. філол. наук: 10.01.08 / АН Украины; Институт литературы. - К., 1992. - 147 с.

Стаття надійшла до редакиї 16.09.2010 p. 